\title{
Law Protection for Tuak Tree (Borassus Sundaicus) in Kupang City of the West Timor Island, East Nusa Tenggara Province, Indonesia
}

\author{
Jimmy Pello ${ }^{1} \&$ Apolonia Diana Sherly da Costa $^{2}$ \\ ${ }^{1}$ Faculty of Law, University of Nusa Cendana, Indonesia \\ ${ }^{2}$ Master Programme in Environment and Urban Studies, Soegijapranata Catholic University, Indonesia \\ Correspondence: Jimmy Pello, SH., MS, Faculty of Law, University of Nusa Cendana, Indonesia. Adisucipto street, \\ Kupang City, West Timor Island, East Nusa Tenggara Province, 85001, Indonesia. Tel: 62-853-3010-8040. \\ E-mail: Jimmypello@yahoo.co.id, Jimmypello1@gmail.com
}

Received: April 16, 2019

doi:10.5539/jgg.v11n2p55
Accepted: May 20, 2019 Online Published: May 30, 2019

URL: http://dx.doi.org/10.5539/jgg.v11n2p55

\begin{abstract}
Lontar tree is one of the biological resources that ecologically has a wide and varied distribution. From the description of Beccari (1913), palm leaves which are growing in Indonesia are Borassus Sundaicus. Lontar tree is a dry land resistant plant that has a wide spread, grows in several areas in Indonesia such as in the eastern part of Java Province (i.e. Madura), Bali, West Nusa Tenggara Province, and East Nusa Tenggara Province (Nusa Tenggara Timur or NTT). NTT is a natural distribution area of palm oil, namely on Timor Island, Flores, Sumba, Savu, Rote and other Islands including in the West Timor Island (Kupang City). For the people in Kupang City, lontar tree is more familiar with the term Tuak tree (Timor's language) or Palm Tree. Tuak tree has benefits for the culture, social, health and economy of the community. However, with various benefits, of course there are problems, namely the existence of threats to the sustainability of its existence. The development in Kupang City has converted the land where Tuak trees are grown for the benefit of government offices, the private sector, residential settlements, the economy, and other public facilities. The threat to the preservation of Tuak trees is also seen in the mindset of local governments and communities who hold firmly a perspective that the Tuak tree is very difficult to be cultivated by the community because it has a natural resistance to its life. The result has been patterned in the community, that the Tuak tree can grow without being planted and mantained. From a legal standpoint, the regional legal norms seem to support the act of transferring the land of the existence of the Tuak tree, even though, the Indonesian national environmental law explicitly instructs legal regulations to take into account the interests of environmental sustainability. The purpose and contribution of this research is to analyze the readiness of regional legal arrangements regarding Green Open Space related to the protection of the carrying capacity of the Tuak tree in its conservation. The contribution of this study as a basis for the consideration of the Indonesian government and the community in planning the establishment of regional laws to support the protection of the Tuak tree in NTT, especially in Kupang City, as well as further research material in the area. This research method was designed as normative and empirical legal research. The normative direction questions the legal regulation aspect from a juridical technical point of view (Dutsch: Tecnischjuridisch begrippen) and also in the realm of legal theory the question of the concept of legal protection for the Tuak tree is questioned. In strengthening conceptual aspects, an empirical legal thinking is inputted to strengthen the conceptual analysis of legal norms. This study uses the Statue approach, Conceptual approach and Case approach. The sources of legal material are in the form of primary and secondary legal materials. The aspects that were studied are the provisions of conservation law related to tree management and protection in order to protect the green open space in Kupang City, where the legal provisions governing follow-up products from the Indonesian national and regional management, determination of Indonesian regional policies relating to management, cultivation, conservation of the Tuak trees and determination of programs related to the conservation of the Tuak trees, which are associated with protection planning policies, conversion of crop land, protection of local food, other follow-up products from palm wine stems and leaves. The results of the study show that the norms in the Kupang City's Regulation Number. 7 Year 2000 concerning the Green Open Space contain more spatial concepts than the green concept of the existence of the Tuak tree as a biological resource. The word "green" refers to trees or plants that live and grow in Kupang City, but in its implementation, the Indonesian regional law dominates these regulations which are supported by an Indonesian policy that always changes due to a pressure on land requirements for development in Kupang City. The regional legal planning for
\end{abstract}


the law protection of the Tuak tree in Kupang City has not received serious attention yet from the Indonesian regional legislative and executive councils. The legal plan for the protection of the Tuak tree is supposed to be carried out under conditions where the population of the Tuak tree has not been disturbed naturally through its management various development interests in Kupang City, in the West Timor Island, East Nusa Tenggara Province, Indonesia.

Keywords: law, kupang city-west timor island-east nusa tenggara province, indonesia, protection, tuak tree

\section{Introduction}

In Indonesia, palm oil is quite varied. From the description of Beccari the type of palm oil that was found in Indonesia is palm oil with B type i.e. sundaicus, while B, fabellifer. It is the plant which was introduced from India in the era of the glory of Hindu Kings (Beccari, 1913, p.7). The stature of these two plants is indeed the same, but it is on different leaf surfaces. Backer and Bakhuizen have identified that the plant was categorized as a B type which the flabellifer leaf surfaces as scaly and B (sundaicus) means that it has a smooth leaf surfaces (Backer and Bakhuizen, 1968).

Lontar is a regional superior product that can be appointed as a national superior product. Lontar is one type of palm plant that has benefits for humans, because almost all parts of palm trees can be utilized starting from the roots to the fruit as food, buildings, household furniture and art and cultural goods. In addition, palm leaves have high adaptability to dry environments. This real potential is a comparative advantage of palm oil compared to other plants.

In East Nusa Tenggara Province, Indonesia, Tuak trees are found on Savu, Rote, Timor, Sumba and Flores Islands. Tuak trees are a kind of local plant that has strengthened the cultural values of the indigenous people lived in the archipelago, including a variety of local foods produced by the community in anticipating food insecurity. The interaction of local communities with trees has shaped the cultural life of the local people's behavior as a culture of drinking tuakor plam tree's wine ('due'). A ti'i langga hat also inspires the construction of traditional houses that are still being used as traditionallyby the local people in the Rote and Savu'ethnic group.

The part of the Tuak tree that is often used, such as: polok, leaves, midribs, fruits, stems and roots of tuak is used for home-making materials, household equipment (mats, house ornaments, household furniture, siri and pinang places in traditional rituals). As a source of food (tuak wine, plate sugar, liquid sugar, sopi, alcohol, palm sugar, palm wine vinegar and rhombus, other food wrappers) and as a raw material for making Sasando musical instruments, traditional caps ( $T$, $i$ langga) already internationally famous. Likewise, the tuak shell can be used as charcoal material which if burned very hot etc.

Ecologically, the tuak tree is a protective plant from natural disasters such as soil erosion due to flooding, exposure to strong winds that always hit coastal areas and mountains in East Nusa Tenggara Province. The tuak tree also has been used by the Kupang Regency Goovernment as a symbol of the local government but its presence in its habitat is not well controlled, especially from data on the presence of tuak trees if the trees provide many benefits to local communities including the overcoming of food insecurity.

The problem that is being faced at this time by the local communities in Kupang City is that the slicer of tuak wine taps the tuak fruit which is male and female so that if it is done by another tuak slicer it will threaten the process of fertilization and the fruit of the tuak embryo. In other words, people used to slice the male fruit, but now tapping into the forerunners of the female parts also, because it produces more tuak water for the needs of the community who drinks the tuak water, for making alcoholic drinks, as raw material for liquid sugar (local term used by the local communities i.e. sugar water) and sugar plate as a result of growing market demand. The water sugar is a raw material for making "sopi" drinks (so called wine from the tuak tree) that have high alcohol content and can also be processed into ethanol raw materials for other purposes.

Development in the Kupang City's area has also penetrated the land where the tuak trees grow. The conversion of land for growing tuak trees for the benefit of Kupang Regency Government and private offices, residential settlements, real estate, hotels, markets and other public facilities. The threat to the preservation of tuak trees is also seen in the mindset of the Kupang Government and the community themselves. Both them hold thought firmly that the tuak plant is very difficult to be cultivated by humans rather than is grow naturally. As a result, it has been patterned to the community that the tuak wine plant can grow without the introduction of humans. Thus, the effort towards the destruction of the life of the tuak trees is not significant with its conservation efforts in terms of the whole plant is very clearly beneficial to the community and the environment in East Nusa Tenggara Province as a semi-arid dry land.

Taking into accountof the many benefits of the tuak tree, the plants should be protected by national law with the 
support of local government policies in the East Nusa Tenggara Province to create conservation behavior for the preservation of the tuak tree. The fact shows that the number of tuak trees does not need to be conserved on the grounds for the number is still large; it is classified as less when compared to the number of tuak trees in Kupang Regency. Like the tuak tree, it must be preserved as well as the land supported by the planning of the formation of regional laws in order to protect it.

\section{Method}

The research method consists of Research Type, Research Scope, Research Approach, Legal Material Sources, The Researched Aspects, Research Techniques, and Legal Material Analysis, as follows:

\subsection{Type of Research}

This type of research is designed as a normative legal and empirical legal research, namely a study that prioritizes aspects of legal presenting. Especially with regard to the formulation of concrete legal regulations governing human behavior in general as well as describing a particular event in relation to environmental protection more specifically to the protection of tuak trees Mertokusumo S (2011, p. 50) further analyzes the relationship between legal provisions in a particular legal category and analyzing the relationship between legal categories is associated with implementing the legal content of green open space management (Hutchinson T, 2002, p.9).

This research is directed at the normative aspects that question about the legal regulation aspects from a juridical technical point of view (Tecnischjuridisch begrippen) and also in the realm of legal theory questioned the aspects of the concept of legal protection. However, to strengthen the conceptual aspect, a little is included in empirical legal thinking to strengthen the conceptual analysis of legal norms (Hademen \& Tatik Sri Djatmiati, 2005).

\subsection{Research Scope}

The research was carried out related to the legal aspects of regional environmental protection planning and its suitability with the implementation of the law of the area of green open space in Kupang City, in the West Timor Island, East Nusa Tenggara Province, Indonesia.

\subsection{Research Approach}

This research can be carried out based on several approaches according to researcher, Hutchinson T (2002, p. 9) which his idea can be detailed as follows:

1. Statue approach is an approach aimed at the applicable legislation and is related to the issue of regional environmental protection and environmental planning research.

2. Conceptual approach is an approach aimed at the legal concept of planning the environmental protection of dry land, especially those that originate from the values that live in the community as outlined in the regional law.

3. Case approach, this approach is aimed at cases that include land use of tuak trees, the yield of tuak trees and associated products which are poured into various regional law products and regional policies.

\subsection{The Legal Material Sources}

Regarding the type of normative legal research, the source of legal material is addressed to primary legal material and secondary legal material. The primary legal materials are laws and regulations relating to the protection of national natural resources planning which includes legislation.

According to Campbell (1996, pp.2-3) legal documents are part of the legal product produced by the legislators (the authoritative records of the law made by the law-making authoritative). Likewise, added by Watt (2001): that primary law is legal material produced by authorized law-making institutions that the primary sources of law are those authoritative records of law made by law-making bodies. The material referred to as Watt includes: laws and regulations, the provisions of orders from executive bodies in the form of regional policies, as well as official reports from the Regional Government regarding objects of regulation.

Secondary legal materials according to Campbell include: reports on government publications relating to matters that are targeted by legal arrangements (the publication that pertain to law which are not themselves authoritative records of legal rules). Furthermore, to see the compatibility between regional regulations and their implementation, primary data was also collected on the existence of the Tuak trees in the location of the green open spaces stipulated in the regional law concerning the green open space of the City of Kupang.

\subsection{The Aspects to be Researched on this Study}


The aspects were examined in this research are as follows:

1. The provisions of the conservation law relating to the provisions of applicable tree conservation laws concerning the management and protection of trees in order to protect the green open space in Kupang City.

2. Legal provisions governing the follow-up products from national and regional management.

3. Determination of regional policies relating to management, cultivation, conservation of tuak wine trees.

4. Determination of programs related to tuak tree conservation is associated with protection planning policies: transfer of plant land, protection of local food, other follow-up products from cast stems, tuak leaves etc.

\subsection{Research Techniques}

Normative legal research examines the comparison of legal norms regarding regulation of tuak trees (legal provisions, legal concepts, formation institutions, forming views on green open spaces. In addition, empirical legal research is also reviewed in aspects of legal implementation of the green open space in Kupang City through a comparison between the contents of green open space and regulations) with the reality in the field.

\subsection{The Legal Material Analysis}

In the management and analysis of legal materials, the first step on this research analysis begins with the investigation of all research results that have to do with the problem of this research. Furthermore, the legal provisions for the regulation of green open space are examined using green concepts that contain trees that occupy the spaces of Kupang City which have to do with research issues, namely planning legal protection for tuak trees before reaching conclusions based on legal instruments that become the basis of this scientific study.

\section{Results and Discussion}

\subsection{Analysis of the readiness of regional legal arrangements regarding Green Open Space related to the protection} of the carrying capacity of the Tuak Tree in its Conservation in Kupang City

Based on the results of the research on the implementation of legal provisions, it is found that there are legal provisions that regulate implicitly with the respect to tuak trees, but the reality in the field due to the will of regional legal norms in the Kupang City is not in line with the legal will of Indoneisan National Regional Law. That Indonesian Regional Law is needed to regulate the specific interests faced by Indonesian Regional Government which is related to the protection of the environment of the region (Kupang City).Thus, the regulation of the existing local legal material is still limited in its scope.

After the law is established, the legal provisions need to be implemented so that the objectives of the establishment of the law are achieved. However, in the reality, yet the implementation of the legal provisions based on the results of the study is not firm in its actions when there are activities that conflict with the contents of the provisions. It was found that when the trees were cut there were legal procedures, but those disobeyed who did the act of felling trees in green open spaces were not regulated, especially if the trees that grow in the open space in Kupang City provide an indication of disturbing the traffic lane and it is not through legal procedures. Moreover, if the action is carried out by the Indonesian Regional Government, then the Indonesian Regional Law is not applicable to the actions of the Indonesian Regional Government on the target of the regulation which is aimed at all parties in the Kupang City. In the context of the tuak tree protection; a question is raised, does the Green Open Space's regulation have the purpose of protecting the tuak tree in its implementation?. This question is discussed on result and discussion section.

\subsubsection{The Determination of Goals Regional Regulations for Green Open Space}

The green areas of city parks in Kupang, green recreation areas of the city, and the areas of legal activities are always in touch with the society. In society, conflicts often occur for they are treated as a rule to regulate the interests of humans in society. Similarly, the relationship between the community and the environment and natural resources requires a legal role in overcoming actions that are less friendly to the environment so that environmental changes are controlled and do not have a negative effect on people's lives.

Kupang City's Regulation Number 7 Year 2000 concerning Green Open Space, as accrodinglyto the general explanation of the local legal provisions, it is explained that: The green open space as a sport and a park area. Some of these concepts are important things that will be realized through the establishment of regional regulations in Kupang City. A question in mind is then raised again, has the will of the provisions of this law been realized in the reality?.

According to the provisions of Part II of the Indonesian Regional Regulation concerning the objectives, functions and benefits of the Indonesian Local Regulation (Peraturan Daerah or Perda) Number 7 Year 2000, especially in 
the provisions of Article 2, it is affirmed that the objectives of the regional regulations are: the creation of a harmonious, balanced with urban environment.

The purpose of the Indoneisan Regional Regulation contains three legal objectives, namely justice (gerechtigkeit), expediency (zweckmaeszigkeit) and legal certainty (rechtssicherkeit). Gustav Radburch teaches that it is necessary to use the principle of priority in determining the purpose of the law, where the first priority is justice, the second is benefit and finally the legal certainty. The three ideas are a legal basis that provides direction in the context of managing urban areas related to the greening space area for Kupang City (Faisal, 2010. p.84).

The regional regulation of green open space requires the environmental management of Kupang City to be such a harmonious condition. Therefore, what is meant by matching the meaning is suitable; it is corresponding; it is to the point; it is in harmony; it is commensurate; it is such a harmonious.

Based on this understanding, the legal provisions require conformity between the ideals of Indonesian Regional Law and the actual reality regarding matters "harmonizing the Kupang City environment, namely there are actions of the citizens of the Kupang City in harmonizing the environment with the conditions of life in the City. In these conditions, actions are needed to harmonize from the whole ranks of the local government in the Kupang City which is together with the citizens in harmonizing the tree planting in an orderly and beautifully manner, in urban spaces that have been allocated according to the Kupang Regional Regulation.

The harmonious value of the Green Open Space requires legal certainty or Rechtssicherkeit that is something new, and it is, since the law is written down, positively publicized and become public. Legal certainty regarding the issue of law, the secrecy durch das recht. Legal certainty is certainty about the law itself (sicherkeit des scherts selbst). There are four things related to legal certainty. First, that the law is positive, which has a meaning that the law (legislation) can be implemented (gesetzliches recht). Second, this law is based on facts (tatsachen), is not a formulation of judgments which will later be carried out by law enforcers such as "goodwill", "politeness". Third, the fact must be formulated in a clear manner so as to avoid mistakes in meaning, besides it was being carried out. Fourth, the positive law cannot be changed frequently.

Based on the legal provisions when compared to the real conditions in the community, it is known as follows: the law of green open space is beautiful in regulation, but it is difficult to protect it as stipulated in its civilian purpose. This is because the supporting institutions in this context, in Indonesia are weak in their law enforcement commitments.

In addition, the community is not well-supported because it is poorly understood that the ultimate goal of implementing the regulation is that if the open space of Kupang City is realized or implemented, it will provide a harmonious comfort in the daily lives of the people. Here, what is meant by a harmonious has a meaning that it is suitable; it is corresponding; it is to the point; in harmony; it is commensurate; it is a harmonious. Based on this understanding, the legal provisions require conformity between the ideals of Indonesian Regional Law and the actual reality related to the following rights: Parks and sports fields, Funeral park areas, Industrial boundaries area, River border areas, Coastal border areas, and he Green cliffs and hills areas, Green lane areas, Agricultural areas, Urban forest areas, Water catchment areas, Areas around springs, Areas around embung, The greenfield areas for important utilities / installations and The green areas for settlement / yard.

In the whole space there are plants in this case the paprika but the existence of trees in the places mentioned above is not neatly arranged because the planting is not planned well neither by the community nor the Kupang Regency Government. The results of this research have shown that the tree planting in Kupang City was carried out on the basis of the idea of greening "which is important for planting trees and can grow". As a result the living trees are not well organized and even they were felling; this phenomenon is not in accordance with the provisions of open spaces within the green open space.

\subsubsection{The existence of Kupang City Park}

There is a Nostalgia park with an area of approximately 2 (two) hectares located around the Kupang City Mayor's Office. The park is a small part of the entire City's park that was arranged in part filled with trees planted. In terms of the beauty of the Park, it does not create the impression of being beautiful how it looks as aesthetically, especially the impression of harmony (comfort) situation because of its location which is flanked by a busy road and surrounded by office and residential areas as well as shops and street vendors.

Based on the arrangement of the garden space there is a place for volleyball / basketball sports and seating and walking trails around the park. This place is also used by the young people in Kupang City to share and chat. From the aesthetic aspects of trees and tree species in the nostalgia garden area, it does not take into account that the types of plants that can support the survival of the park in the future because the choice of long-lived age trees is 
not suitable for learning from other Indonesian national parks. In short, the nostalgia park stands out as a momentary stop for not reacting and also does not fulfill its function as a garden overgrown with trees that are aesthetically and ecologically valuable and that was not shady though.

\subsubsection{The Funeral Park Location}

Based on the results of research on the location (park) of cemeteries in Kupang City has not shown the concept of the park and still shows a haunted impression. There are a number of locations or burial sites as follows:

- Kapadala tomb in Maupoli

- Fatufeto's tomb in Fatufeto

- Kelapa Lima's coastal area: cemetery

- Tomb of Solor Village in Kampung Solor Village

- Grave of Love in Naioni Village

- $\quad$ Freedom Tomb next to the east of the Merdeka stadium

- Naimata's tomb in Naimata Village

- Penfui's tomb in Penfui Village

- Tomb of the Heroes in the Village of Kelapa lima

- Graves of Families / Clans in all villages

- Eat individuals in all villages. From the tomb there is a well-maintained tomb condition only at the Tomb of Love and the Tomb of the Heroes, while the other tombs are not maintained (Result of Fieldwork about the Funeral Park in Kupang City, 2013).

\subsubsection{Industrial Border Area}

Dealing with industrial border areas that the area requires business owner actions to build the industrial area, for a green lane area, it did an observation. Based on observations on location, especially in the industrial area in Bolok / Tenau Kupang, it is known that there are few green areas with various types of trees, including a few tuak trees and acacia trees (kabesak), kusambi, beringin, angsono, pine with levels a place to grow trees that is not evenly distributed in industrial estates.

Based on the results of the study, it is known that the whole place of the tomb is not well maintained and is also not seen as a tomb park, except the garden of the tomb of the hero and the tomb of love, but the green concept is not yet specifically managed by the Local Government of Kupang Regency. Whereas the location of the other tombs is not managed because the problem is that its management is not well organized and seems to have a lack of management.

When it is compared with the purpose of the regional regulation concerning funeral park, in which there are trees, the overall tomb does not show as a tomb park that has a function of green open space. This can happen because the initial use of the place to be used as a place to eat is absolutely having no concept of the park and it is more associated as a sacred place. Likewise, the spatial and aesthetic concepts of the park which are not considered. As a result of what is now happening that the parking lot does not have, the road to access to the tomb's location and it looks narrow as well as the layout or position of the grave plots is not organized, and it seems slum. In other words, the existence of grave plots in the Kupang City is separated from the concept of the park. This can happen because the initial set as a place of residence is not taken into account the concept of the park and the land is narrow and land use is also available in residential buildings, shopping areas and other areas with different functions of space. In short, the place of the tomb is like this, if it is connected with the location of the buildings around it and the designation of buildings separated from the unity of the space where the tomb is located.

There is also an area of economic growth on the coast of the Timor Island, there are Local Government buildings, residential buildings with uneven distribution from Namosain to Lasiana Beach. In addition, there are hotel and market facilities and the means of involvement blend in with the trees on the coast in the area around the Namosain bridge and Fatufeto. There are a group of tuak trees which are also threatened by land eviction or it does not have aesthetic value.

\subsubsection{River, Coast, Cliff and Hill Areas}

The results of the study on the implementation of the Local Regulation Number 7 Year 2000 concerning green 
open space in the area of rivers, beaches, cliffs and hills in Kupang City, there are growing areas that can beautify the Kupang City with which its not in harmony and unbalance. The results of the study show that there are trees in some of these areas but are not neatly arranged because of the growth of trees around this area. The types of trees in the form of Tamarind, Lamtoro, Acacia, Flamboyant, Kusambi, Gamal, Iron Wood. The settlement buildings began to penetrate the river slopes and coastal borders so that it disturbed the existence of trees and also careless garbage disposal.

\subsubsection{Green Line Area of Kupang City}

The results of this study have shown that the green lane of Kupang City was commensurate with the road starting from the road lane in Kowil leading to the eastern part of Kupang City that is on the Piet A Tallo road and in front of the Ina Boi road lane, there were quite a lot of trees planted and began to show their lushness but they were not organized neatly including the type of plant. Overall, there are 19 tuak trees, acacia trees, paper flowers, mango trees, johar, flamboyant, pine, kusambi, angsana, gamal, nitas and grass, etc. The presence of these trees was not well organized because the planting was done haphazardly.

\subsubsection{Agricultural Area}

The agricultural area in Kupang City is in the Oepuravillage and Naioni Subdistrict. There is a tendency for the function of green open spaces due to the vagueness of the layout of aspects of green open space. This can be seen from the development of various buildings that continue to penetrate the area so that the green open space continues to decrease in area. Vegetables and fruits are cultivated in the area for the needs of the community as well as in the rice fields in the rainy season where the owners of rice fields try to plant rice and planted corn in the summer.

Specifically, for the Oepura village area in Kupang City, it is knowns as an underground water source area, but its development in the area has penetrated the area around the location of the water source and there is no tuak tree in the area. There are also residential buildings that are unregulated and show an increasing number of buildings without being controlled by the agency that manages the building permits, so it is feared that it will reduce the area of green open space in Oepura village.

\subsubsection{The Urban Forest Area}

Thie urban forest areais located in two locations, namely Airnona and the Nusa Cendana University; it is roundabout where this land belongs to the Indonesian Air Force. For the trees that grow in the area even though they are not maintained and are also allowed to grow naturally, the trees's location is often used as a waste disposal site and there are also no tuak trees even when the road is cleared, a number of trees are cut down without legal procedures.

\subsubsection{Water Infiltration Area, Water Source, around Embung in Kupang City}

In the area of water sources, the existing trees also grow naturally and neglected because what is considered is the fulfillment of the need for water resources rather than structuring the trees on the water sources. Likewise, residential buildings around the area also interfere with the hygiene of water resources (Oetona, Oepura, Oeba, Oebobo, Air Nona, Bakunase).

\subsubsection{Green Line Area Utility / Crucial Installation}

The results of the study show that the trees around the important installations are not organized and also the location of growth is haphazard with angsana trees, frangipani and other trees.

\subsubsection{Green Settlement Region/Courtyard}

The results of the study haveshown that the settlements of the people in Kupang City were more organized even though they were less tidy with ornamental plants for landowners whose yards were narrow and settlements that had sufficiently strong yards had fruit plants (manggo, kedondong and a few other fruit plants). The buildings and plants look unbalanced in their position, giving rise to the impression that they are not neat and the trees that have their lives are left alone.

The existence of the tuak tree is very rarely found implicitly in the legal regulation of the city's green open space through the green concept. This is related to the weakness of Indonesian Regional Institutions in enforcing the rules, especially related to the felling of tuak trees related to the conversion of its land in the event that the tree is of ecological, has of an economic value and it supports local people's culture.

3.2 The Planning for Establishing the Indonesian Regional Law to Support the Protection of Tuak Trees in Kupang City, in the West Timor of East Nusa Tenggara Province, Indonesia

Based on the results of research related to the planning of legal protection for tuak trees, it is a realization of a plan 
in the regional development of Kupang City through the formation of Indonesian Regional Laws to support the preservation of the area's natural resources. In order to achieve these objectives, a legal planning is the first step to early control the existence of biological natural resources in their habitat and also in the development area. The Indonesian Regional Regulations are formed in order to carry out the mandate of a higher law containing the principle of sustainable development.

In Kupang City, there was a change in the function of the space which resulted in the destruction of the tuak tree because the land where it grew was used for the construction of economic areas, hotels and also people's settlements because it was not included in the planning of the place where the tuak trees should be protected. This can occur because of changes in the policy of the regional government to make changes to the allotment of land including the green open space in Kupang City to fulfill the demand for the land from economic actors in the region.

In addition, the ecological value of the tuak tree is not taken into account in terms of legal protection rather than the economic value of the development of the Kupang business centers. This condition occurs because of the unification of the power of economic actors with the Regional Government bureaucracies in a mindset that is different from the pre-determined of local law. The strong influence is indirectly supported also by the lack of commitment to implement Regional Government oversight of the compliance of economic actors implementing the provisions of regional law. This is also reinforced by the unplanned action plan for integrated regional law enforcement from various related institutions and also concerning the availability of budgeted operational funds. This can occur because there is a growing number of tuak trees in the Kupang city area, but the regional offices in charge of regional plantation business do not have enough available information about the existence of these resources because there are special policy changes that are not targeted by the program.

Destruction of the tuak tree also occurs because the place of growing palm trees is in a strategic position according to the calculations of business people and also supported by the policy of changing the function of local government land. The existence of a tuak tree has ecological, social, cultural and economic values which in its management are very seriously needed by legal planning from the function of legal protection. Therefore, it is necessary to prepare data and information on the existence of tuak trees in supporting decision making by various stakeholders in planning making regional law and its preservation. Noting the legal provisions regarding the International Plant Protection Convention in Article 3 of the convention, it is stated that:

- the surveillance of growing plants, including both areas under cultivation (inter alia fields, plantations, nurseries, gardens, greenhouses and laboratories) and wild flora, and of plants and plant products in storage or in transportation, particularly with the object of reporting the occurrence, outbreak and spread of pests, and of controlling those pests, including the reporting referred to under Article VIII paragraph 1(a); (International Plant Protection Convention, 1997).

These legal provisions require the supervision of growing plants, including in cultivation areas (fields such as plantations, nurseries, gardens, greenhouses and laboratories), wild flora, plants and plant products in storage or transportation, especially reporting the outbreak and spread of pests, and pest control.

When linked to the results of research in the field, it is known that the regional legal planning related to the management of palm trees in Kupang City did not receive separate attention from the regional legislative and executive circles because the existence of these trees was counted in countless numbers. If you pay attention to the international legal provisions regarding crop protection, FAO has confirmed in Rome, Italy November 7, 1997 that:

Each contracting party shall make provision, to the best of its ability, for the following:

- the distribution of information within the territory of the contracting party regarding regulated pests and the means of their prevention and control;

- research and investigation in the field of plant protection;

- the issuance of phytosanitary regulations; and

- the performance of such other functions as may be required for the implementation of this Convention (International Plant Protection Convention, 1997, p.1).

For the regional government in Kupang City about the legal provisions and also the provisions of Article 44 of UUPPLH 32 of 2009 and also the Regional Government Law Article 17 can be the legal basis for the protection of the tuak tree.

The results of the study show that the hidden threat to the life of the tuak tree continues because it occupies strategic 
land for the construction of malls, settlements, offices and other buildings. This condition can occur because it is seen by the bureaucrats that the tuak tree has a lot of distribution, but it is not known exactly which data is actually in nature.

In addition, the phenomenon of showing the direction of destruction of the palm trees continues because the land where the palm trees grow is very strategic land for economic activities and other activities so that the life of the palm trees continues to be pushed in Kupang City.

Legal planning for the protection of tuak trees is carried out at least in conditions where the population of palm trees has not been disturbed through tree management for residential development needs, production of tuak water for human needs (tuak water drinks, making sugar cubes, taking tuak for community consumption etc.).

In the context of Indonesian law, the state has the task of ensuring the sustainability of local plants for the welfare of their people. In addition, in the fourth paragraph of the opening of the 1945 Constitution, it is stated that: protect the entire Indonesian nation and the whole of the bloodshed of Indonesia and to promote public welfare, educate the nation's life, and participate in carrying out world order based on freedom, eternal peace and social justice. The ideal idea was also stated in the elaboration of Article 33 paragraph (2) also emphasized that production branches which are important for the state that control the livelihood of many people.

Based on the provisions which were outlined by the Indonesian Constitution, 1945 above, the state is obliged to carry out an effective plan to achieve that goal. The state gives the authority to realize the objectives contained in the Indonesian Constitution, 1945 to the executive councils (the Indonesian President and his ranks of cabinet including the regional leaders).

According to the authority of the Indonesian State and Regional Governments, the issues about policies were discussed such as regional communities including conservation, policies on food, agriculture, economy, transportation, housing, and other sectors in the region. However, in recent times the Indonesian Government's policy was felt to be less in favor of the life of the tuak tree as has been confirmed by the objectives of the Indonesian Constitution, 1945.

One reason stated by the Local Government is that the eviction of tuak land for road construction projects and industrial development that touches the interests of the local people in space, so that the use of green open spaces with reasons for the development of the hospitality industry in Kupang City still supports regional legal instruments. The problem is that at the beginning of the spatial planning the area was to be used, as it is today not included in the area for hotel activities but as an area which is associated with the Bolok industrial area along with the residential area. This can happen because the detailed plan of the Kupang City space has been late and the activities have preceded the establishment and enactment of legal instruments for detailed regional space planning.

For Kupang City there is green open space in office space, schools, colleges, residential settlements, river slopes, beach borders, inner-city central lane and residential and office buildings. In some of the mentioned spaces there is a very little presence of thetuak trees because when these lands are needed the presence of tuak trees and it is considered to interfere with the position of various forms of construction which are then to be built and tuak trees are always calculated as low economic value compared to the land.

Historically, the open space, which one example, here it is so called Taman Kota (Park), it was initially seen as an area which is outside the Kupang City and this can be seen in the past planning of the agency or institution with an interest in the forest. Along with the well-known increasingly concept of green open space (City forest) the concept of Parks (garden where there are some plants such as flowers) that are outside or between several buildings in urban environments is beginning to change and the combination of the concept of Parks and urban forests.

Initially, the green open space was intended as an area which is outside the city and it is now known as a yard or outer space which has a variety of plants in the Park and forest with a concept. The Park and forest are later developed into the term green pen space of the Kupang City. Both the Park and forest is generally seen as an open space which is deliberately planted by the Local Government with the trees and plants, as a ground cover. There are also planted productive crops in the form of fruit trees and vegetable plants and they are now presenting as part of green open space in the form of urban agricultural land or urban forest land that is very important for maintaining the ecological balance function of the Kupang City. The regional legal arrangements which are related to green open space in Kupang City want a function from green open space which its space can provide comfort, security, and sustainable productivity set in Article 3 of the Local Regulation Number 7 Year 2000.

Based on the results of research on several local legal provisions in Kupang City that regulate the City's environment and also its implementation, it is known that there are no legal provisions that regulate legal protection for tuak trees as regulated by the East Nusa Tenggara Province's Government regarding The Regional Regulation 
on Sandalwood.

Noting the pattern of regulation which prioritizes the supple and simple aspects of the theoretical aspects, it turns out that it has little implications for the efforts to preserve the tuak tree in real terms. In fact, the existence of these regulations provides a broad space for various groups to interpret freely that various types of trees may be introduced into spaces in Kupang City, including efforts to replace the position of tuak trees as specific local plants that have high endemic values. As a result, the legal conditions that are less assertive in its implementation seem to provide indirect reinforcement to the economic actors and the Regional Government of Kupang City in calculating the continuity of the tuak tree in the area that has always been used for land conversion. This was happened, because of the strong position of the Regional Government of Kupang City which acts as the regional ruler, offering lucrative land prices offered by economic actors and intermediaries to landowners.

In addition, there is also a strong lobbying or negotiation of economic actors with the Regional Government in an effort to determine the change in the area where the tuak trees are converted as an area prepared for economic activities rather than ecological thinking so that the logging of tuak trees in Kupang City takes a place by ignoring the provisions of green space regulations. This is similar to the events or phenomenon in China based on the results of Gao Boyang's research et al. in China which his research's results were stated:

"However, industrial relocation involves not only negotiations between government and firms, but is also a game played among different levels of government. National, provincial, municipal, county and even rural level governments bargain with each other to shape and gain from the relocation of industries (Boyang., Weidong \& Dunford, 2014,)

Therefore, from the implementation of the law of green open space is related to the management of trees in open space, the aspect of spatial use is more prominent than the effort to protect the existence of trees. Furthermore, the urban spaces that are vulnerable to land conversion are from what was originally determined. This condition is also supported by the substance of legal arrangements relating to tuak trees in general (it is implied by the phrase "green open space" which can be seen in the formulation of the legal provisions of Kupang City which is described as follows:

\subsubsection{Regional Regulation in Kupang City Year 200 Number 7 about Green Open Space}

According to the provisions of Article 1 letter (f) green open space is defined as a part of urban spatial planning that functions as a green area of sports activities, urban green parks, urban green areas, urban green recreation areas, green activities by sports, funeral green areas, green agriculture area, green lane area and green yard area.

Based on the understanding of green open space, the existence of the tuak tree is very likely to grow in some of these open spaces and this is of course supported also by the local legal provisions of Kupang city regarding the Regional Spatial Planning. This is evident in the concept of greenopen space which is emphasizing spatial concepts related to the concept of urban forests in which there are various types of both large and small plants including tuak trees. Likewise, the concept of urban forest is a stretch of physical component consisting of vegetation in the form of trees as a unit of ecosystem; it is also functioning as a unit of the environment. Similarly, the definition of urban forest according to the provisions of Indonesian Government Regulation Number 63 Year 2002 concerning Urban Forests stated in Article 1 that lift 3: Urban forest is a stretch of land overgrown with compact trees and meetings in urban areas that are on the State Land or Land Rights designated as urban forest by an authorized official.

The definition of urban forest in terms of land inKupang City, by the Mayor of Kupang City, among others, regulates specifically based on the Regulation of Mayor Kupang Number 14 (a) Year 2011 concerning the Establishment of Urban Forest Areas in Kupang Region. It is stipulated by the Mayor of Kupang in connection with the use of land of the El Tari Kupang Air Force-Base covering an area of 20 hectars to be used as a forest area in Kupang City. While, the other land is owned by the Regional Government of Kupang City, it is also reforested with trees (stretch of road) but it is not with tuak trees rather the plants were introduced and there were also other local tree species.

Noting the green open space's condition of Kupang City and it is being connected with the places were categorized as green lanes, there are many types of trees introduced and it is not including tuak trees because the texture of the trees is less attractive to decorate the Kupang's green open space and there is also an assumption that it is difficult to be maintained and arranged. If it is managed by certain groups with an aesthetic approach and combined with cultural and ecological values (eco-tourism), the characteristics of the Kupang City will be seen.

3.2.2 Habits: Drinkingthe Tuak tree's water and Eating its fruit (seboak fruit)

For the people in Kupang City, drinking tuak is consumed by children, parents as thirst-releasing refreshments on 
the roadside or at home. Likewise, drinking laru as a result of the process of tuak water or it is made from a liquid sugar and is usually drunk by men as well as not being left behind by female camps in the suburbs in Kupang City such as the tuak (laru) sale area around the Naimata Urban Village, they gather drinking the laru also includes freshly tapped sweet tuak wine. However, in general, men who do not process the water from the drinker's house. A glass of tuak in Medan costs around 300 Indonesian rupiah $(0.3$ cent $\$$ ) while the tuak sweet wine per 1 jerry can of 5 liters its price is 100,000 Indonesian rupiah (10\$). Likewise, the price of laru is made of 1 bottle of tuak water, its price 2000 Indonesian rupiah ( 2 cent \$). The same prices go for the price of laru which it is made from water sugar per bottle, its price is 2000 Indonesian rupiah ( 2 cent \$). There is also a tuak's slicing group that taps the tuak wine from male fruit and also from the female fruit as to obtain plenty of tuak water just to meet the needs of long drinks for people who live on the outskirts of Kupang City.

Seboak fruit is also very popular with the people taken from fruits that are still quite easy to usually cut and then taken intact fruit meat to be sold with a picnic around the Kupang City to the public, the price of plastic is 5,000 Indonesian rupiah ( 5 cent $\$$ ). This condition shows that the tuak fruit is very popular among the people as a local fruit food and is actually a tradition in the Rote, Savu and also other ethnic people in East Nusa Tenggara Province. The Seboak fruit is consumed as a fresh fruit and is sold by several roadside sellers.

There is also a habit of people who are eating meat from the fruit that is picked as young as local fruit. It is still found in Kupang City where sellers sell the seboak fruit meat that has been taken from the fruit and sold in plastic bags. The bag contains 10 grains of meat where its price is around 2500-5000 Indonesian rupiah (2.5-5 cent $\$$ ). It was peddled and walking around public places that are usually visited by sellers for this.

\subsubsection{The Use of Tuak tree in Social Services}

The Tuak which has to do with the habit of voluntary workof the local people or gathering to release fatigue or just gathering with acquaintances in an ordinary meeting and then served its water or laru which comes from the fermentation of tuak water. The sweet rice is slightly sour and slightly bitter (it is containing alcohol). Almost every day in the season, tapping the tuak fruit and prviding the tuak fresh water for a sell in the market, it is always sold by the local people. Uniqueally, it is happened, when especially with the number of tuak trees where their fruitsare tapped around a treeand the sellers sell the tuak water in the tree. The yield of income can produce around one hundred ofjerry cans of 20 liters which its price is20,000-25,000 (2-2.5 \$) then the slicer of tuak will get a pretty good profit for his life. The use of tuak's water in social service events will strengthen the sense of mutual cooperation among society and also to fulfill the habit of drinking laru. Through drinking the laru, drinkers can also create and strengthen such social relations.

\subsubsection{The Transferring Function of the Tuak Tree}

The change in function of the tuaktree's land may happen because the development of urban areas in various sectors which always targets the land where the tuak trees grow because their lives are spread over the Kupang city area with a limited area. On the other hand, the need for land is relatively high so that it is easy to suppress the spaces where the trees grow. In addition, the development in this area, especially the population of uncontrolled settlements besides using land where the tuak trees grow, is also targeted as building material.

At present the tuak tree is seen as an economically and culturally valuable tree but is not protected by law and it lacks for an appropriate award. Mostly, due to unconsciousness, these open spaces (including green open spaces) are actually of economic value and at the same time it has a high ecology which is vital for the sustainability of the lives of residents in urban environments. By taking into account the current conditions that the development and management of urban green open space areas must be a hierarchically accommodated substance in legislation and regulations and guidelines at the national and regional / city level, the regional and sub-regional spaces are then strengthened by The Regional Regulations. In its implementation, development and management of green open space also involves the community to increase their appreciation and concern for, especially, the quality of the urban natural environment, which tends to decline.

3.2.5 The Main Issue Regarding the Availability and Sustainability of the TuakTree for a Green Open Space in Kupang City

The negative impact of the suboptimalization of palm trees in green open space where Kupang city green open space does not meet the requirements of quantity and quality (non-functional green open space, land fragmentation which reduces land capacity and subsequently decreases environmental capacity, land use and function) occurs mainly in form:

- Reducing city comfort: decreasing capacity and carrying capacity of the region (disruption to land whose function has been set at the start of planning so that it is deviated from increasing, groundwater availability 
decreases, city temperature increases, etc.).

- Reducing the security of the city was marked by the emergence of criminal acts in Kuta Kupang.

- Reducing the natural beauty of the city (natural amenities), especially in coastal areas of the city of Kupang.

- Reducing the level of community welfare (decreasing public health physically and psychologically).

The results of the study on the implementation of the legal provisions of Peraturn Daerah Number 7 Year 2000 concerning the City of Kupang Green Open Space based on the legal provisions of RTH often experienced land conversion, logging of action trees according to legal procedures and land placement and activities deviating from the Kupang city space plan which had been agreed in the Kupang City Spatial Planning.

\subsubsection{Two Weaknesses Role of the Stakeholders in Kupang City}

- The weaknesses perception of the community in protecting the space intended for legal protection for the tuak tree.

- The weaknesses understanding of the community and Local Government about the protection of tuak wine trees.

\subsubsection{The Limitation of City Land for an Open green Space' Designation (Tuak tree Conservation)}

The optimal use of open land in Kupang City for its functional green space (tuak tree planting) has an impact on the limitation of Kupang's City land.

According to the legal provisions of Indonesian Minister of Public Works' Regulation Number 05 / PRT / M / Year 2008 concerning Guidelines for Provision and Utilization of Green Open Space in Urban Areas, regulating green open space is an elongated area or lane or group which uses more open spaces, where plants grow both naturally and deliberately planted. This is an opportunity for the conservation of tuak trees, but the community views that the tuak tree is difficult to grow if humans plant it.

\subsubsection{The Regulator of a Green Open Space}

The preservation of the green open space in Kupang City requires Institutions that are consistent in implementing the protection of green open spaces from the threat of land conversion. The fact that changes in green open space in Kupang City is without a direct control done by the authorized Institutions even it is based on the experience so far from the local law enforcement, working on the aspect which is related to the functioning of the green open space in Kupang City. It has not touched the law because the regional Institutions do not process violations of green space regulations. Likewise, with the conservation of tuak trees which is not included in regional conservation planning with several weaknesses. These wekanesses are explained as follows:

- The existence of regional legal regulations governing the green open space in Kupang City but the regulations were not yet fully adhered to by the community related to awareness of managing the environment that still needs to be improved.

- There was no any optimal enforcement of the rules for the management of green open space.

- An unclear form of green open space management managed by the Institutions.

- There is no work procedure for green open space management that is in accordance with the situation in Kupang City.

\section{Closing}

This closing consists of conclusion and recommendation as described below.

\subsection{Conclusion}

The existence of the tuak tree is very rarely found in the legal arrangements of the urban green open space which are implicitly regulated in the regulation of the legal area of the green open space through the green concept. This is related to the weakness of the Indonesian Regional Institutions in enforcing the rules, especially related to the felling of tuak trees and its conversion land in the event that the tree is of ecological, economic value and supports local culture.

The planning of Local Regulations in East Nusa Tenggara Province regarding the protection of tuak trees emphasizesmore the green open space aspect in line with the spatial concept. However, the implementation of the layout concept was more prominent because of the influence of land conversion policies for economic interests.

\subsection{Recommendation}

Based on the conclusions, some recommendation are drawn as follows: 
- The revision and preparation of the legal umbrella for the area of urban green open space, especially the concept of green open space, needs to pay attention on, to the continuity of the palm tree in Kupang City.

- The compilation of General Guidelines related to the Construction of Green Open Space and the Management of Open Green Space.

- The empowerment and improvement of community participation in managing the conservation of palm wine trees.

- $\quad$ There should be a declaration ations for the Movement to Build, Maintain, and Manage the Tuak trees in Kupang City i.e. Green Space Area and the program alike for the local people in the City to consume fruits.

- It is expected to increase the function of open land in Kupang City to Green Space Area which is planted with Tuak trees and an improvement in the extent of private green open space.

- The need of functional pilot on green open projects for narrow lands, marginal lands, and neglected lands.

\section{References}

Backer, C. A., \& R. C. Bakhuizen van den Brink Jr. (1968). Flora of Java. WoltersNoordhoff N.V-Groningen The Netherlands.

Beccari, O. (1913). Distribution, Originand Cultivation of the Coconut Palm.Webbia, 4(7).

Boyang, Gao., Weidong, L., \& Dunford, M. (2014). State Land Policy, Land Markets and Geographies of Manufacturing: The case of Beijing, China. Abstract, Journal Elsevier Homepage: Retrieved from www.elsevier.com/locate/landusepol

Campbell, E., et. al. (1996). Legal Research Materials and Method. Sydney: The Law Book Company.

Faisal. (2010). Menerobos Positivisme Hukum. Yogyakarta: Rangkang Education, p. 84.

Government RegulationYear 2002 Number 63 about Urban Forest.

Hadjon, P. M., \& Tatik Sri Djatmiati. (2005). Good Governance dalam Penyelenggaraan Pemeritahaan Daerah (Perspektiv Hukum Tata Negara dan Hukum Administrasi). Jurnal Meritokrasi, 1(1). Makasar: Hasanuddin University Press.

Hutchinson, T. (2002). Researching and Writing in Law. Sydney: Lawbook Co, p. 9.

Indonesian Constitution, Year 1945.

International Plant Protection Convention. (1997). Food and Agriculture. Organisation (FAO).

Mayor Regulation of Kupang CityYear 2011 Number 14A about Determination of Urban Forest Area in Kupang City

Mertokusumo, S. (2011). Teori Hukum. Jogyakarta : Universitas Asmadjaya, p.50.

Regional RegulationYear 2000 Number 7 about Open Green Space.

Regulation Year 2009 Number 32 about Environmental Protection and Management.

Regulation Year 2014 Number 23 about Regional Government.

Tambunan, P. (2010). Potensi dan Kebijakan Pengembangan Lontar Untuk Menambah Pendapatan Penduduk (The Potential and Policy for Lontar Development to Increase the People Income). Jurnal Analisis Kebijakan Kehutanan, $\quad 7(1), \quad 29 . \quad$ Retrieved from http://ejournal.forda-mof.org/ejournal litbang/index.php/JAKK/article/view/268

Watt R. (2001). Concise Legal Research. Fourth Rdition. Sydney: The Federation Press.

\section{Copyrights}

Copyright for this article is retained by the author(s), with first publication rights granted to the journal.

This is an open-access article distributed under the terms and conditions of the Creative Commons Attribution license (http://creativecommons.org/licenses/by/4.0/). 